\title{
Conflict and Sovereignty. The Debate between the United States and the European Union
}

DOI: $10.35757 /$ CIV.2009.11.05

The war in Iraq was ended after a short period of time. The dictatorship of Saddam Hussein has been abolished. In the few months that followed the announcement of the end of the war campaign, it turned out that the main aim of this war, which was to obtain peace, to rebuild the civilization and economy of a nation, to establish the rudiments of a stable political system which would respect basic human rights (which, as the leaders assured, was necessary for establishing a democratic system in Iraq) would require more time, patience, skill in dealing with Iraqis and, contrary to what the Americans had presupposed, the involvement of more countries and international institutions, and therefore the investment of more diplomatic efforts in the international arena as well. The military objective, which was to annihilate a regime unresponsive to the rights of its citizens (or rather subjects) and thus dangerous for the world peace, was attained. However, what was politically named the casus belli- the possession of weapons of mass destruction by Hussein's regime

Miłowit Kuniński - Ph.D., professor and director of the Institute of Philosophy of the Jagiellonian University, President of the Centre for Political Thought (Ośrodek Myśli Politycznej) in Cracow. 
- was in fact never unanimously confirmed. No weapons were ever found, while American and British leaders continued to be censured by their national public opinion.

The main opponents of the armed intervention in Iraq, an intervention without an international community sanction (whatever is meant by the term "international community" - a kind of poor synonym for the United Nations, or rather an expression of the dissatisfaction of those countries that are important players in international politics), refrained from any strong criticism against the main players of the coalition forces in Iraq. This moderation, these displays of generosity in the name of unity and peace, particularly on the part of such significant European Union countries as France and Germany, was noted even much earlier, when the war in Iraq was drawing to its close. One could probably conclude that even the adversaries themselves were in no position to foresee the extent of the discord, and tried to make efforts to minimize these elements of disunity, despite the fact that it was too late.

The conciliatory gestures of politicians may be acknowledged as an expression of the desire to resuscitate political stability in the Western World, which in turn was violated by the differences in opinion on how significant changes should be introduced in Iraq and the rest of the region. The unity of the Western World was shaken not only during the preparations for the war in Iraq, but also while the war itself was taking place. This was not the first time when such a tension and a clash of values in the West has been observed, however this time the need to reexamine various opinions and attitudes and rebuilt friendly relations has become more urgent. Besides, it would be difficult to imagine a long-term acceptance of the conflict of opinion among the western countries, which in turn would have serious consequences for the distribution of power on the global scale. 


\section{The Conflicting Nature of the Crisis}

One can certainly draw the conclusion that we are dealing with a profound and long-lasting crisis at the core of the Western World, caused by the fall of the communist system - as many have already pointed out - which changed the previous distribution of power and enabled a clearer and more open redefinition of the interests of its main political actors. This crisis will be characterized by irregular outbursts of aggressive activity, often far exceeding the norms of diplomatic correctness, by periods of collaborative effort, particularly if the West faces serious threats on a more global scale and has to deal with serious political games. It is certain that the main source of this present crisis is the rivalry that has been waged on various fronts between the US and the European Union.

This stark contrast between the European Union (its main pillars being France and Germany) and the United States was most evident during the reign of Saddam Hussein, in the period that preceded the war. The powerful and aggressive responses on both sides of the Atlantic have caused a wave of commentaries through which one might perceive the essence of the conflict. As always the differences of interests: political, economic and strategic ones, were often blamed, but also differences in cultures and differences in the role of tradition, the European consciousness of the complexity of the problem as opposed to the American tendency to simplification, the French faults and ingratitude, the internal situation in Germany and the WWII German complex syndrome, etc. Stereotypes, bilateral and aggressively-formulated accusations and resentment, often deeply hidden, typified the debates. 


\section{Hobbes or Kant?}

One of the few, who has attempted to provide a more general overview of the nature of the problem was Robert Kagan. ${ }^{1}$ According to him, the reason for the crisis rest upon the different political philosophies that inspired the decisions of the adversaries. Americans would opt for Thomas Hobbes and his realistic perception of the area of the relations between countries as a natural state, where rivalry takes place, the enemy is fought off, and when necessary, force should be used. Europeans, according to Kagan, have been the followers of Immanuel Kant, who would often look for the need to respect a universally observed laws, executed by international institutions, the source and guarantee of peace on an international scale. For Europeans, diplomacy and persuasion are the means necessary to achieve the rule of order on an international scale. Americans often rely on the efficiency of counterattack threats (while it is true that this often results in a great deal of negative experiences and results in their own mistakes), while Europeans rely on the stability of an order based on law.

Most of these comments, despite being emotional and often simplistic in nature, are often characterized by a dose of good sense, and their arguments reveal the various aspects of this complicated situation. Robert Kagan's text, in this respect, stands out in a more positive light. He is undoubtedly right in pointing out circumstances in which appealing to the law is insufficient, since the circumstances are extraordinary.

Many in the past, in their reflections on politics, have noted exceptional situations (an echo of this is the concept of the state of emergency, often appearing in constitutions), and the necessity to go beyond the limits foreseen as legal and legitimate forms of activity.

R. Kagan: Power and Weakness, "Policy Review," June-July 2002. 
Many thinkers have always been aware of this fact. Medieval philosophers (whose contribution to this discussion seems to have been forgotten) such as St. Thomas Aquinas, ("necessity knows no law" - necessitas legem non habet), later ones such as Niccoló Machiavelli, Thomas Hobbes and, of the more contemporary ones, Carl Schmitt, have mentioned this problem as well. Georg Jellinek, a follower of the liberal concept of the law of the state, emphasizes in his book Allgemeine Staatslehre (General Theory of the State) that "law has never possessed an influential force in the running of a state during moments of crisis." These thinkers did not function within a virtual reality, they often reflected on the philosophical aspects of day-to-day politics, and in doing so often tried to examine the basic rules and necessities that govern politics. Should we accept Kagan's reasoning, we might reach the reasonable conclusion that Americans are in fact conducting politics in a manner not far from the traditional European practices and standards. It is definitely true, however, that their way of doing politics has been shaped by a century of rivalry and the desire for domination.

Does this clash between America and Europe testify to the fact that, in recent years, i.e. after 1989, conducting politics has indeed undergone some fundamental changes? Is the European model of conducting politics more modern and appropriate to the evolution that has taken place in the Western world, in which the order of the law and the protection of the entitlement of citizens, as it has been demonstrated before, has become the basis of political and social order, while the United States on the other hand, upholds the old principles of Realpolitik, formerly a European specialty?

I certainly would have serious objections to this. To put it in a more illustrative language: one's bite is often conditioned by one's teeth. The United States has teeth, while Europe has false ones. I am not saying that trusting diplomacy, respecting human rights, international law, international institutions is a symptom 
of military and economic weakness. These factors might certainly play a substantial role, though they are all secondary to others, which certainly have a more fundamental significance.

On the other hand, shortly after Hussein's reign was overthrown there were voices that argued for the need to strengthen the common ideals and interests of both sides. Gestures of courtesy and goodwill abounded in demonstrating and emphasizing that, in fact, the conflict that resulted from the war in Iraq was based on a misunderstanding, on the lack of the necessary goodwill to explain differing standpoints, which certainly did not threaten the coherence of the Western World, not to mention the unity of the Atlantic allies. In fact, another issue was at play: the safeguarding of private interests and the exploitation of the situation, in which the Americans overthrew Hussein's regime in order to gain even more benefits for themselves. There were journalists though, such as Timothy Garton Ash, who were unconstrained by the norms of politics and diplomacy and tried to look further, exhorting the need to rebuild the unity of Europe, a unity that has been definitely shaken ${ }^{2}$.

\section{The Function of Conflict and Legal Institutional Activity in the Creation of Political Sovereignty}

To formulate the thesis of this article more precisely, I would say that the deep and stable foundation of this crisis (to the degree that is possible in politics) between the relations of Europe (or to be more precise: of the European Union) and the United States, rests on the substantial differences in the character of the state sovereignty of both sides. The United States is a country of a well-formed state sovereignty (i.e., external sovereignty), and not

2 Timothy Garton Ash: Anti-Europeanism in America, "The New York Review of Books," February 13, 2003. 
only in terms of the international law. Such a country is capable of implementing its will in its relations with other countries, i.e., it is an active player in foreign policymaking, capable of achieving accepted goals (though whether these goals may be enduring enough or not is another question), and able to make decisions and implement the resolutions resulting from the strategy and political tactics adopted. This capacity to react quickly (in the military sense as well) to changing international situations, especially when a threat arises, is closely related to the manner of decision making. In the system of the political institutions of the United States, decision processes may take place rather quickly, as they may be adopted and implemented quickly as well. This is because its political system and practice have endowed the president with a wide range of responsibilities, while maintaining the principle of checks and balances.

The European Union, however, is not an active player in the international political arena. Two institutions are certainly equipped with such an active role in politics: The European Community, which comprises the first pillar (The Economic and Monetary Union), along with other European Communities: The European Atomic Energy Community (Euratom) and the European Community (formerly the European Economic Community).

However:

1. The EU does have certain elements of both international and legal autonomy, since it contains certain conventions within the second pillar (the Common Foreign and Security Policy system joined with the Western European Union) and the European Security and Defense Policy, or fourth pillar;

2. The legal autonomy of the European Union within the EU is implemented in the third pillar - in the Common Policy of Justice and Internal Affairs;

3. The EU is meant to have an international and legal autonomy according to a project of the Constitutional Treaty which is 
being prepared by the European Convention (Art. 6 of the Treaty Establishing a Constitution for Europe Draft holds that the "Union shall have a legal personality").

It is affirmed that the legal personality of a state is implemented neither by the will of its institutions (the Church or other states) nor its nations, but through its own will (which does not preclude the agreement of the will of the state with that of the nation). It is in this respect that one can speak of sovereignty (internal or external) that implements will within the borders of a state. Sovereignty may be a fact, obtained through a legal form. This does make the status of the European Union rather ambiguous, however. It does have certain areas of real sovereignty and it may be expressed legally, through a legal personality, while on the whole it finds itself in the phase of developing its sovereignty, of granting itself a legal personality.

In practice, the European Union's relies on the European law (and treaties in particular), clearly demonstrating that its tendency is to strengthen its external sovereignty, while possessing an internal sovereignty at least to a certain extent; both of these, however, are limited by the present boundaries of the sovereignty of the Member States. This decision process in the European Union's case is long, complicated and ineffective, often being the source of conflicts and disagreements between the Member States, who carry out their own foreign policies. A compromise to open the road to a common ground is hardly attainable, and meanwhile decisions are generally made by countries like France and Germany, sometimes Great Britain, who often think, for one reason or another (such as tradition, the role of being the founding fathers, ambition, political and economic interests), that they can lead the European Union. Yet even in such cases, the radicalism of the decision is limited by the multi-state character of the EU. The limitations of the EU's sovereignty are gradually being better understood, bearing in mind that it still is in its embryonic stage. In fact, the sovereignty of the EU still remains more of a mission 
than a reality; it still finds itself in the process of development, of adopting its political and institutional realities to the formal and legal nature of the sovereignty of its political being, that is, in acknowledging the EU as a self-governing body in international law. A manifestation of this aspiration towards the validation of sovereignty and the creation of a legal treaty basis for to build and strengthen the sovereignty of the EU was the recently approved in the Draft Treaty Establishing a Constitution for Europe, which in turn has initiated a debate on the ultimate institutional shape of the EU. The proposed solutions have, as we know all too well, provoked different reactions and triggered other debates on the ultimate shape of the EU, particularly on the boundaries of its internal and external sovereignty.

This crisis on the Washington and Brussels line has its causes in the EU's search for a real and internationally recognized legal formula of sovereignty in the international arena. It is for this reason that the foreign policies of France and Germany should not arouse any doubts or astonishment, but can be and usually are objects of criticism.

What is the simplest way of effectively exercising influence in international politics? Certainly, by expressing a clearly defined and separate stance, in opposition to others' opinions. An exceptional situation often best serves this purpose. It is conflict by nature, since it forces one to clearly support a given solution, i.e. to take a clear stance in support of a particular side. It is obvious that a prolonged decision-making process often facilitates the search for compromise and tends to blur responsibility by enlarging the number of participants. If the European Union were a state of a federal nature, as suggested by the constitutional draft of the EU, the policy-making would be more unified, real and would consist in the manifestation of external sovereignty. The European Union, being neither a unitary nor a federal state, but rather a confederation, in which foreign policy is the result of compromise, is doomed to random policy-making or domination 
by the larger states and their less significant allies within the EU. Should, however, the European Union adopt the form of a federal state, then the scope of its responsibilities, particularly in the fields of foreign and defense policies, but in the field of economics as well, will be much broader and covered within certain exclusion clauses, in accordance with the constitution draft. This is clearly defined by the content of Articles 12 and 15 of the draft, which among other points precisely states the content of Article 1, establishing the European Union and defining the principle of the division of competence among the European Union and its Member States and coordinating their policies. ${ }^{3}$ In this way, the authors of the Draft Treaty Establishing the Constitution for Europe not only define the sovereign character of the future European Union, which in principle means that they are affirming the traditional understanding of sovereignty (particularly in an

\footnotetext{
3 Article 1: Establishment of the Union

Reflecting the will of the citizens and States of Europe to build a common future, this Constitution establishes European Union, on which the Member States confer competences to attain objectives they have in common. The Union shall coordinate the policies by which the Member States aim to achieve these objectives, and shall exercise in the Community way the competences they confer on it.

Article 12: Exclusive competence

1 The Union shall have exclusive competence to establish the competition rules necessary for the functioning of the internal market, and in the following areas:

- monetary policy, for the Member States which have adopted the euro,

- common commercial policy,

- customs union,

- the conservation of marine biological resources under the common fisheries policy.

2 The Union shall have exclusive competence for the conclusion of an international agreement when its conclusion is provided in a legislative act of the Union, is necessary to enable it to exercise internal competence, or affects an internal Union act.

Article 15: The Common Foreign and Security Policy

The Union's competence in matters of common foreign and security policy shall cover areas of foreign policy and all questions relating to the Union's security, including the progressive framing of a common defence policy, which might lead to a common defence.

Member States shall actively and unreservedly support the Union's common foreign and security policy in a spirit of loyalty and mutual solidarity and shall comply with the acts adopted by the Union in this area. They shall refrain from action contrary to the Union's interests or likely to impair its effectiveness.

(The Draft Treaty Establishing a Constitution for Europe of July 18th, 2003. The text was accessed from the Internet website of the Secretariat of the European Convention - the service of the Office of the Committee for European Integration http://www.europe.bg/ upload/docs/Constitution_for_Europe_Draft_EN.pdf).
} 
internal sense), that is characteristic of nation states. The authors of this draft essentially intend to hasten the process of achieving complete sovereignty for the EU. It is a question whether the extent of integration achieved within the Union and established practice in conducting unified foreign policy form a sufficient basis for investing the Union with a new legal form, or whether the authors of the draft are acting on the assumption that it is the law which shapes the mature form of sovereignty. It is hard to avoid the impression that they are in fact convinced that constitutional solutions are demiurgical forces that do not just put affairs in order, but rather create a new state of affairs.

\section{The Sovereignty of the European Union or the Sovereignty of Dominating Member States?}

If the aim inspiring the forces which clearly tend to invest the Union with a defined sovereignty may be acknowledged as reasonable (though this does not mean that it should deserve acceptance), then the manner of implementing it could only lead to some essential doubts.

Firstly, this kind of sovereignty should above all be declarative in character.

Secondly, the political system of institutions seeking to realize this sovereignty serves to link the institutional forms existing to date and their often overlapping competencies with the new solutions, which perhaps simplify certain procedures, yet also trigger conflicts, for they seldom take the real political situation into account. That is to say, they often overlook the fact that the nation states comprising the Union really exist, along with their conflicting interests, and not only as legal structures defined by the constitution draft. 
Thirdly, constructing the sovereignty of the European Union constitution draft consciously and specifying the manners of decision making favors the stronger nation states: France and Germany. Put simply, does this not signify that the sovereignty of the Union will in fact be realized by the dominant nation states becoming sovereigns of the other Member States? If a system of representation in which states represented the entire Union was established, this would certainly be a clearer solution, though it is difficult to imagine that this would be accepted by the states represented. Another formula then remains which would not inhibit the states, but would allow them to truly exercise the function of a sovereign.

It is thus obvious that by this understanding the sovereignty of foreign policy becomes (actually, it already is to a significant extent) the expression of sovereignty of these states, and not of the Union as a whole. Many centuries of experience have taught us that the relation between states is based on rivalry, and though it need not be military in character, it carries on continuously. The participants of this rivalry must conduct themselves according to the rational rules of the game, acting under uncertain conditions: the future is unknown and knowledge of the other players' moves is often based on suppositions. The condition of competing and of gaining the upper hand is the opportunity to plan and make decisions. Otherwise, one remains on the periphery of the game, gaining nothing, and moreover: systematically losing ground.

The leaders of the European Union are aware of this; however, the participation of the Union in the wider arena of international politics is two-sided: the factual and legal-institutional nature of the Member States and the Community, and ultimately that of the Union as a whole. The activities of the European Union as a whole may serve in the de facto securing of its external sovereignty. The resolutions of the draft constitution establishing the aims of the Union mention this clearly when they refer to the Union as a political body implementing a foreign and security policies, and 
in the future, a defense policy. It also acts as a political body when it refers to the citizens of the Member States, when it talks of defending their rights and interests in the Union's relations with other states resulting from establishing EU citizenship. This practice leads to certain legal consequences which would confirm in iure, and thus strengthen, the sovereignty attained.

In order to obtain external sovereignty certain practical steps must be taken, an institutional solution and a corresponding legal establishment within the internal forum. In other words, external sovereignty demands the establishment of internal sovereignty. The interdependence between these two forms of sovereignty is often of a dual nature. It is usually the case that active participation in the international arena clearly strengthens internal sovereignty, regardless of whether it is conducted with such an intention or whether it is predetermined by certain external circumstances. The active participation of the European Union in world politics is undoubtedly of the first category, and war in Iraq has certainly provided favorable conditions. In Poland's case, the weakness of the state and rickety internal sovereignty were strengthened by Poland's involvement in the Iraq War and support for the US, resulting in Poland's unexpectedly gaining significant status in the international arena.

In the case of the EU however, we can observe an interesting process of internal sovereignty being shaped:

In the internal forum:

- the tendency to create the institutional and legal basis for a common foreign and security policy, and a defense policy as well. The intention to create a Ministry of Foreign Affairs and common defense forces;

- the preparations of a legal (constitutional) character for the creation of a European state equipped with the attributes of a nation state: a federal system, chief head of state, and a hard core of the European Union (the largest and the richest Member States); 
- debates concerning the cultural dimension and mentality of a European State: the European identity as a cultural equivalent of European citizenship;

- the role of the nation states which aim to maintain and extend their real influence on the form of institutional changes.

In the external forum:

- an inspiring ideal: the weakening of the position of the United States in the international arena for the purpose of creating a multilateral order out of fear of US domination (though it is striking to note the lack of fear of the domination of Russia, China or any of the Islam countries who have nuclear, biological and chemical weapons at their disposal);

- a more open policy towards Russia: the strengthening of a multilateral order and control over the processes of change within the country accompanied by a complimentary civilizing mission (this is less about real influence than intention);

- the policy towards the United States: the critique of American policy in the Middle East and toward the Saddam Hussein regime during the implementation of United Nations Resolution No. 1441, in the time of the preparations for war on Iraq, and while it was in progress;

- the spreading of the EU towards the East for the purpose of widening its human potential and sphere of influence, while it continued to gain critical mass that affecting its relations to other states;

- EU countries' decisions to join forces in military operations for the purpose of demonstrating the existence of combined armed forces prepared to intervene in other countries (i.e. the EU-sanctioned intervention of three EU countries in the Democratic Republic of Congo).

The establishment of the internal sovereignty of the EU is being implemented in principle according to the norms of how modern (nation) states obtained their sovereignty, regardless of their federal or more centralized structure. If we accept that 
the nature of international relations between countries should coincide with the Hobbesian model, and many arguments do in fact support this, then we can state that in the last fifty years European integration has taken place gradually, but in in two clear stages:

- through closer economic collaboration among some states the creation of an international civil society based on the relations of exchange with elements of solidarity and subsidiarity - a partial solution to the Hobbesian dilemma within Western Europe;

- the creation of interstate and suprastate structures for the purposes of building a political society and a European State - a more advanced solution to the Hobbesian dilemma. ${ }^{4}$

The weakening of hostile tendencies amongst the European States within the boundaries of the European Economic Community, later the European Community and the European Union, would be the necessary condition to facilitate more effective participation in international competition. This would mean that solving the Hobbesian dilemma within the EU would not lead to its solution on the wider international scale. The idea of a world state, which from the perspective of the internal logic of political theory could lead to a solution to this dilemma on an international level, is an illusion, a devout hope which ignores the inevitability of rivalry between states, regardless of the complexity of their constitutional structures and decision-making processes. Kant's perpetual peace on a European scale may be permanent, for it could be acknowledged that the institutional basis for it has been established; however, this political creation, of which the European Union is a perfect example, will compete with other

\footnotetext{
4 The concept of the Hobbesian dilemma and its solution is usually applied to clarify the phenomenon of a political power on the level of the state (Cf. J. Gray: Limited Government: A Positive Agenda, IEA, London 1989, pp. 29-32). The European Union may be treated as an attempt at finding a solution to that dilemma on the interstate level within a defined and limited territory. The creation of a worldwide state, that is, the establishment of a Kantian perpetual peace, would be a solution to Hobbes's dilemma on the global level.
} 
states. Solving the Hobbesian dilemma on an international scale seems impossible because of the lack of a real external threat, which would force the establishment of the basis for the external sovereignty of the world state. The invasion of a Martian army or economic rivalry with Venus is but the stuff of science fiction. The Hobbesian model of sovereignty is a reality demanding the will to face another will, that is, of another sovereignty.

As Hobbes wrote, "that Man to Man is a kind of God; and that Man to Man is an arrant Wolfe. The first is true, if we compare Citizens amongst themselves; and the second, if we compare Cities. In the one, there is some analogie of similitude with the Deity, to wit, Justice and Charity, the twin-sisters of peace: But in the other, Good men must defend themselves by taking to them for a Sanctuary the two daughters of War, Deceipt and Violence: that is in plaine termes a meer brutall Rapacity. ${ }^{. "}$

Perhaps in the European Union we are approaching a state of European citizenship (I am not referring here to the present legally-obliging EU citizenship), and that is why people shall be like gods to one another; however, in interstate relations we are doomed to rapacity or subordination, as among wild animals, where the defending our territory and intimidating potential enemies is the condition of survival. That is why external sovereignty needs opposition, or, to put it in the spirit of C. Schmitt's words, sovereignty reveals its true nature in exceptional situations, in situations of conflict.

It can be therefore affirmed that, from the point of view of the logic of political transformation, the Union must aim toward an external sovereignty. This process will certainly be a long one, and will undoubtedly involve recurring frictions between the European Union and the United States. This will be the symptom of the process of building the sovereignty in opposition to a state

\footnotetext{
5 T. Hobbes: De Cive: The Philosophical Rudiments of Government and Society, Dedication and Preface. Internet version available at http://www.constitution.org/th/decive00.htm, accessed March 6th, 2009.
} 
whose legal and international sovereignty cannot be questioned, and whose practical sovereignty has been expressed in the active participation in the international arena for almost 200 years.

This particular feature of the building process of the sovereignty of the European Union is reactive by nature. This is unlike the United States, where isolationalist tendencies have always existed alongside other tendencies, and whose outlet has become a policy of governing the world, maintaining an international order and intervening in major crisis situations. The policy of European Union is marked, on the other hand, by being cumbersome and indecisive, which can be explained on the one hand by the Kantian legalism and tendency toward the building of an international order based on law and international institutions which serve to establish and execute it, and on the other, by political intervention (even armed) that is accepted and even strongly supported by major EU institutions when the interests of European colonial states in the former colonies are threatened. This only proves that the concern for legal and peaceful order is of secondary significance when other interests, such as those mentioned above, are at stake.

The European Union is the result of an underdeveloped external sovereignty linked with weak internal sovereignty, therefore:

- it avoids making decisions which would demand initiative and the will to influence the course of events and political, financial and military involvement, both of a preventive and an interventionist character;

- the European Union is other-directed; that is, it reacts to frictions and crises, attempting to act in a way that often counteracts American policy, trying to prove the independence of the EU;

- a substitute for the as-yet unformed internal and external sovereignty is the national sovereignty of some of the Members States, mainly that of France and Germany, and also of Belgium, for example; those same real roles on the international scene are played by nation states, who impose their traditions of sovereignty 
on the domestic and international level; as a result, we are in reality dealing with a Hobbesian situation in the international forum, though presented as action in favour of the implementation of the rule of law on an international scale;

- the building of the sovereignty of the European Union is an irreversible process; however, its form and institutional procedure remain to be clearly determined and defined.

\section{Some Conclusions for Poland}

Because the sovereignty of the European Union finds itself in statu nascendi, the concluding work of the Convent and the initiated constitutional debates have a crucial role to play in the future shape of the Union and the fate of the new states that should wish to join. Poland, like other countries that find themselves in a similar position, must look for an answer to the form of EU sovereignty, the shape of the European state system: should it be a centralized state, a federal or a confederate one, with a strong government, a strong parliament, a head of state, of a common foreign and defense policy, created by states forming the hard core of the EU, or should it take the path of compromise, (reached either through majority rule or through finding unanimity) within a larger group, with all its members, etc $^{6}$. Do we have our own stance? Will we have to defend it? Will it be respected? Certainly, unless we are to yield to the illusion that the only way that leads to this new period of change is the humble acceptance of the imposed conditions. There are no rational arguments for strengthening EU sovereignty at the price of renouncing our national participation in the process. The sovereignty of the European Union should be founded on the nation states, who together decide on the actions of the EU as

${ }^{6}$ Poland joined the EU on $1^{\text {st }}$ May of 2004. 
a whole. Since the European Union cannot become a nation state, because - as has been already emphasized many times before - there is no one united European nation existing as a sovereign, and only the nations of the Member States can fulfill this role ${ }^{7}$.

Translated by Clarinda Calma

Fitrst edition: Konflikt a suwerenność: spór między Stanami Zjednoczonymi a Unia Europejska, "Civitas. Studia z Filozofii Polityki" 2003, vol. 7, pp. 161-177 .

\footnotetext{
Cf. for instance R. Scruton: The West and the Rest. Globalization and the Terrorist Threat, Intercollegiate Studies Institute, Wilmington, Del. 2002, and A. Hall: Koszty, które warto zapłacić [The Costs Worth Paying], "Rzeczpospolita" (daily), no. 224, September 25 2003.
} 